\title{
Effects of roxazyme-G on growth indices and haematological variables of broilers fed maize offal-based diets
}

\author{
O.P.A. OLOWU ${ }^{1}$, J.O. AGBEDE ${ }^{2 *}$, S.O. ARO ${ }^{2}$ and V.A. ALETOR ${ }^{2}$ \\ ${ }^{I}$ Department of Animal Science, Federal College of Agriculture, Akure, Nigeria. \\ ${ }^{2}$ Department of Animal Production and Health, Federal University of Technology, P.M.B. 704, \\ Akure, Nigeria. \\ ${ }^{*}$ Corresponding author E-mail: joagbede @yahoo.com
}

\begin{abstract}
Influence of roxazyme- $G$ on the utilization of maize offal was investigated using 420 broiler chicks and 210 (5-week old) growing broilers at starter and finisher phases, respectively. A basal diet that met the nutrient requirement for each phase was formulated and used for the trial. Basal diet meant for starter phase contained $529 \mathrm{~g} \mathrm{~kg}^{-1}$ maize while basal diet for finisher phase contained $569 \mathrm{~g} \mathrm{~kg}^{-1}$ maize. For each phase, $25 \%$ or $50 \%$ maize component of each basal diet were replaced with maize offal. Thereafter, the maize offal-based diets were divided into 3 equal parts and designated diets 2, 3 and 4 for diets in which its $25 \%$ maize component was replaced with maize offal and diets 5,6 and 7 for those with their $50 \%$ maize components replaced with maize offal. Roxazyme- $G$ was added to the diets at levels of 100,200 and $300 \mathrm{mg} \mathrm{kg}^{-1}$ in diets $2 \& 5,3 \& 6$ and $4 \& 7$, respectively. The birds were fed their respective diets for 21 days. At the close of the starter (2-4 weeks of age) and finisher (5-8 weeks of age) phases 10 chicks and 10 chickens per replicate, respectively were sacrificed conventionally and their blood collected for blood analysis. Of the growth indices measured only the final weight of chicks was significantly $(\mathrm{P} \leq 0.05)$ influenced by the dietary treatment. The entire haematological indices measured were not significantly $(\mathrm{P} \geq 0.05)$ influenced by dietary treatment in both starter and finisher birds. At starter phase, the optimum level of maize offal inclusion could be achieved at $132.3 \mathrm{~g} \mathrm{~kg}^{-1}+200 \mathrm{mg}$ $\mathrm{kg}^{-1}$ roxazyme $-G$ while $142.3 \mathrm{~g} \mathrm{~kg}^{-1}$ maize offal $+200 \mathrm{mg} \mathrm{kg}^{-1}$ roxazyme- $G$ was for finishers. Conclusively, the use of maize offal and roxazyme $-G$ at these optimal levels could lead to more of maize offal being included in broiler diets in tropical countries.
\end{abstract}

() 2012 International Formulae Group. All rights reserved.

Keywords: Finisher, maize offal, starter, roxazyme-G.

\section{INTRODUCTION}

Report by Nnenna et al. (2006) and recently by Aro et al. (2010) showed that agricultural by-products have in recent years become important dietary component for non- ruminant animals in most tropical countries, including Nigeria. Maize offal is a byproduct obtained from maize grain after wet or dry milling of maize. Its potential as filler or energy diluents in non-ruminant 
feeding has been reported by Uko et al. (1999) and Iyayi (2004). Birds fed on such feeds have poor feed consumption and a concomitant reduced weight gain and, this according to Agbede et al. (2005) could be attributed to high dietary fibre content.

Conceivably, improving the nutritive value of this fibrous ingredient could lead to more of it been incorporated in non-ruminant diets in tropical countries. Improved utilization of maize offal by non-ruminant could be achieved if such maize offal-based diets are supplemented with exogenous enzymes such as roxazyme-G. Roxazyme- $G$ is an enzyme produced by fungus (Trichoderma). It's potential in reducing the viscosity of intestinal content with an improved feed utilization after consumption of non-starch polysaccharides (NSP) by nonruminant have been reported by Pitson et al. (1993) and Agbede et al. (2002). However, to our knowledge, it appears that there are limited studies conducted to examine the influence of roxazyme- $G$ on the utilization of maize offal by broilers. Consequently, this study was conducted to examine the utilization of maize offal by broiler chickens as influenced by roxazyme-G using performance and blood indices as response criteria.

\section{MATERIALS AND METHODS}

\section{Experimental diets}

Two basal diets were formulated to meet NRC (1994) requirements for broiler starter and finisher (Table 1). At both starter and finisher phases, the two basal diets contained $529 \mathrm{~g} \mathrm{~kg}^{-1}$ and $569 \mathrm{~g} \mathrm{~kg}^{-1}$ maize, respectively without enzyme or maize offal. For each phase, $25 \%$ or $50 \%$ maize component of each basal diet were replaced with maize offal. Each diet with their maize replaced at 25 or $50 \%$ maize offal was mixed in one batch, divided to three equal portions and designated diets $2,3 \& 4$ for diets in which its $25 \%$ maize component was replaced with maize offal and diets 5,6 \& 7 for those with their $50 \%$ maize components replaced with maize offal. Roxazyme- $G$ was added to the diets at and above the manufacturer recommended levels of 100, 200 and $300 \mathrm{mg}$ $\mathrm{kg}^{-1}$ in diets $2 \& 5,3 \& 6$ and $4 \& 7$, respectively.

\section{Animal management and experimental Layout \\ Starter phase}

A batch of 420 day-old Arbor Acre broiler chicks were obtained from Ajanla farms, Ibadan, Nigeria. The chicks were electrically brooded together on the floor for the first three days during which they were sexed as described by Laseinde and Oluyemi (1997). The chicks were thereafter transferred into metal metabolism cages which have facilities for faecal collection. During the preexperimental period, the chicks were fed on commercial feed (Livestock feed: $230 \mathrm{~g} \mathrm{~kg}^{-1}$ crude protein; $11.97 \mathrm{MJkg}^{-1} \mathrm{ME}$ ). After the first week, the chicks were randomly divided into seven groups of sixty (60) such that the groups mean weights were similar in a completely randomized design. The treatments were replicated thrice with 20 birds (10 males +10 females) per replicate. The birds were fed for 21 days with their respective experimental diets. The routine veterinary practices as outlined by the Teaching and Research farm of the Federal University of Technology, Akure, were followed.

\section{Finisher phase}

Two hundred and ten 5 weeks old growing broiler birds left from the starter 
phase were used for this trial. Prior to the commencement of the trial, the birds were fed on commercial feed (Livestock feed: $21 \mathrm{~g} \mathrm{~kg}^{-1}$ crude protein; $12.6 \mathrm{MJkg}^{-1} \mathrm{ME}$ ). The birds were randomly divided into seven groups of thirty (30) each in a completely randomized design. The treatments were replicated thrice with 10 birds (5 males and 5 females) per replicate. This phase also lasted for 21 days.

\section{Blood collection}

Three hours to the close of the finisher phase, the birds were starved so as to empty the crops and weighed. Thereafter, five males and five females were randomly selected per replicate in each phase and all were sacrificed conventionally by severing the jugular veins with sharp knives. The blood was then allowed to flow freely into labeled bijou bottles which contained a speck of Ethylene Diamine Tetra Acetic Acid (EDTA) for analysis.

\section{Analyses}

The proximate composition of the ingredients used before the feed formulation and the test diet samples were analyzed by the methods of A.O.A.C (1990). The microKjeldahl method was used for crude protein determination (\% $\mathrm{N} \times 6.25)$ while the soxhlet extraction method was used for fat determination. The crude fibre was determined by alkali and acid hydrolysis of the feed samples. The packed cell volume (PCV) was estimated by spinning about $75 \mathrm{u}^{1}$ of each blood sample in heparininzed capillary tubes in a haematocrit micro centrifuge for 5 minutes while the total red blood cell count (rbc) was determined using normal saline as the diluting fluid. The haemoglobin concentration (Hbc) was estimated using cyanomethaemoglobin method while the erythrocyte sedimentation rate (ESR) was determined as described by Lamb (1981).

\section{Calculation and statistical analyses}

The performance indices were calculated per unit bird. The weight gain was calculated by subtracting the initial weight of birds from the final weight. The average weekly feed consumption was calculated as the total feed consumed for the experimental days divided by the number of weeks while the feed conversion ratio (FCR) was the ratio of average feed consumed to average weight gain. The mean corpuscular haemoglobin concentration (MCHC), mean corpuscular haemoglobin $(\mathrm{MCH})$ and the mean corpuscular volume (MCV) were calculated as described by Lamb (1981) as follows:

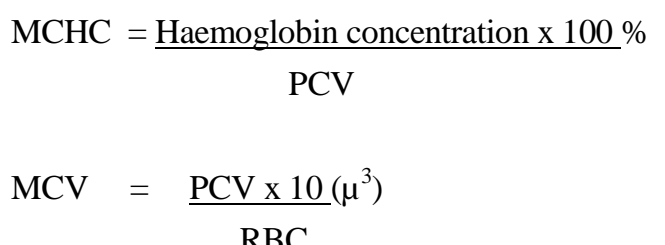
statistical analysis using analysis of variance (ANOVA) of SPSS 15 (2006) package. The significant treatment means were compared using the Duncan option of the same software.

\section{RESULTS AND DISCUSSION}

\section{Performance indices}

Table 2 shows that only the final weight $(\mathrm{FW})$ of the chicks were significantly $(\mathrm{P} \leq 0.05)$ influenced by the dietary treatment. Chicks on the basal diet had the highest FW $(547.2 \pm 1.0 \mathrm{~g})$ and this was significantly $(\mathrm{P} \leq 0.05)$ higher than those fed the test diets with chicks on $50 \%$ maize offal +200 $\mathrm{mg} \mathrm{kg}^{-1}$ roxazyme-G-based diet having the 


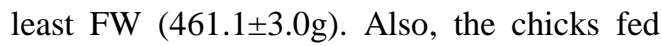
on $25 \%$ and $50 \%$ maize offal + enzyme-based diets had $7.7-10.7 \%$ and $10.4-15.7 \%$ respectively, lesser weight than those on the basal diet. This observation could be attributed to the inability of the chicks to effectively digest and utilize the dietary fibre of maize offal-based diets despite the roxazyme- $G$ inclusion. While this observation is consistent with earlier report by (Ojewola et al., 2003), it is contrary to the reports by Vranjes and Wenk, (1995), Alp et al. (1999) and Agbede et al. (2002) that roxazyme-G enhances growth performance in poultry. Furthermore, chicks on diets containing 25\% maize offal in most cases had higher FW, average weight gain (AWG) and average feed consumption (AFC) than those on $50 \%$ maize offal-based diets suggesting that the optimum level of maize offal substitution for maize in starter diet could be achieved at $25 \%$ but with roxazyme- $G$ inclusion level at $200 \mathrm{mg} \mathrm{kg}^{-1}$.

At the finisher phase, the FW, AWG, AFC and feed conversion ratio (FCR) of chickens on the basal diet were not significantly $(\mathrm{P} \geq 0.05)$ different from those fed on the test diets (Table 2). The non significant differences observed could be attributed partly to roxazyme- $G$ inclusion which led to improve digestibility, absorption and utilization of non starch polysaccharide (NSP) by chickens on maize offal-based diets. This is achievable by unlocking the nutrients in maize offal-based diets through reduction in gut viscosity in the intestinal lumen by the enzyme. Also, it could be attributed to the ability of adult birds to tolerate higher dietary fibre than the chicks. This could be due to the well developed gizzard of the adult birds (Agbede et al., 2005). Birds on 25\% Maize offal + roxazyme$G$ diets had higher FW than those fed $50 \%$ Maize offal + roxazyme $-G$ when compared on level to level of enzyme supplementation
(1790 vs $1660 \mathrm{~g}),(1800 \mathrm{vs} 1710 \mathrm{~g})$ and (1770 vs $1750 \mathrm{~g}$ ) for $100 \mathrm{mg}, 200 \mathrm{mg}$ and 300 $\mathrm{mg} \mathrm{kg}^{-1}$, respectively, but this was not significant. However, this further confirms that the optimum level of maize offal inclusion in broiler finisher diets is $25 \%$ with 100 or $200 \mathrm{mg} \mathrm{kg}^{-1}$ roxazyme-G supplementation.

\section{Haematological studies}

Table 3 shows that the haematological variables of the chicks were not significantly $(\mathrm{P} \geq 0.05)$ influenced by the dietary treatments. However, the PCV ranged: 25.3- 28.3\%, RBC 1.9-3.0 x10 $\mathrm{mm}^{3}$, Hbc 4.0-5.3 g/100 ml, MCHC 15.4-19.4\%, MCV 90.7-147.4 $\mu^{3} \mathrm{~m}$ and ESR 2.5-4.3 $\mathrm{mmhr}^{-1}$. Also at the finisher phase (Table 4), all the haematological variables evaluated were not significantly $(\mathrm{P} \geq 0.05)$ influenced by dietary treatments but the group fed on $50 \%$ maize offal $+300 \mathrm{mg}$ $\mathrm{kg}^{-1}$ roxazyme $-G$ had in most cases the least values for the haematological variables (except MCV and ESR).

The haematological values obtained for the finished birds were in most cases lower than those reported for broilers fed maggotbased diets by Awoniyi et al. (2004). For instance, a range of $29.7-34 \% \mathrm{PCV}, 2.2-2.7$ $\mathrm{RBC} \times 10^{6} \mathrm{~mm}^{3}$ and 7.5-8.0 g/100ml Hbc was report by Awoniyi et al. (2004). The values obtained for PCV, RBC and Hbc in birds fed the test diets were similar to those fed the basal diets at both phases, thus indicating the potential of roxazyme- $G$ at improving the nutritive value of maize offal-based diets in such away that they promoted identical blood synthetic activities in the experimental birds. Similarly, the values of MCHC and MCV for chickens fed on the basal and test diets were similar. This could imply that all the blood samples collected and analyzed had similar 
O.P.A. OLOWU et al. / Int. J. Biol. Chem. Sci. 6(1): 307-316, 2012

Table 1: Basal composition of experimental diets $\left(\mathrm{g} \mathrm{kg}^{-1}\right)$.

\begin{tabular}{|c|c|c|c|c|c|c|}
\hline \multirow{3}{*}{$\begin{array}{l}\text { Phases } \\
\text { \% Maize offal } \\
\text { Roxazyme-G }\end{array}$} & \multicolumn{3}{|c|}{ Starter } & \multicolumn{3}{|c|}{ Finisher } \\
\hline & \multirow{2}{*}{$\begin{array}{l}\text { Basal } \\
\text { 0 }\end{array}$} & $25 \%$ (diets 2-4) & $50 \%$ (diets 5-7) & \multirow{2}{*}{$\begin{array}{l}\text { Basal } \\
\text { 0 }\end{array}$} & $25 \%$ (diets 2-4) & $50 \%$ (diets 5-7) \\
\hline & & $\longleftarrow 100$ & $\mathrm{~kg}^{-1} \longrightarrow$ & & - 100-3 & $\mathrm{g}^{-1} \longrightarrow$ \\
\hline Maize & 529.0 & 396.7 & 264.5 & 569.0 & 426.6 & 284.5 \\
\hline Maize offal & - & 132.3 & 264.5 & - & 142.3 & 284.5 \\
\hline Soya bean meal & 340.0 & 340.0 & 340.0 & 330.0 & 330.0 & 330.0 \\
\hline Fishmeal & 30.0 & 30.0 & 30.0 & - & - & - \\
\hline Others* & 131.0 & 131.0 & 131.0 & 101.0 & 101.0 & 101.0 \\
\hline Total & 1000.0 & 1000.0 & 1000.0 & 1000.0 & 1000.0 & 1000.0 \\
\hline \multicolumn{7}{|l|}{ Calculated } \\
\hline $\mathrm{CP}\left(\mathrm{g} \mathrm{kg}^{-1}\right)$ & 230.0 & 230.0 & 230.0 & 212.0 & 212.0 & 213.0 \\
\hline $\mathrm{ME}\left(\mathrm{MJ} \mathrm{kg}^{-1}\right)$ & 12.2 & 12.1 & 12.0 & 12.3 & 12.2 & 12.1 \\
\hline Cyst +Meth (\%) & 0.9 & 0.9 & 0.8 & 0.8 & 0.8 & 0.8 \\
\hline Leucine $(\%)$ & 2.0 & 2.0 & 2.0 & 1.9 & 1.9 & 1.9 \\
\hline \multicolumn{7}{|l|}{ Analyzed } \\
\hline $\mathrm{CP} \quad\left(\mathrm{g} \mathrm{kg}^{-1}\right)$ & 233.0 & 233.0 & 230.0 & 213.0 & 210.0 & 211.0 \\
\hline Crude fibre “ & 31.0 & 43.0 & 52.0 & 42.0 & 55.0 & 63.0 \\
\hline Ether extract “" & 13.0 & 21.0 & 11.0 & 24.0 & 20.6 & 12.3 \\
\hline
\end{tabular}


O.P.A. OLOWU et al. / Int. J. Biol. Chem. Sci. 6(1): 307-316, 2012

Table 2: Performance indices of broilers fed maize offal-based diets with roxazyme-G supplementation.

\begin{tabular}{|c|c|c|c|c|c|c|c|}
\hline Diets & $\begin{array}{l}\% \text { maize } \\
\text { replaced } \\
\text { with } \\
\text { maize offal }\end{array}$ & $\begin{array}{l}\text { Enzyme } \\
\text { inclusion } \\
\left(\mathrm{mgkg}^{-1}\right)\end{array}$ & Initial weight & Final weight & $\begin{array}{l}\text { Average } \\
\text { weight } \\
\text { gain/chick/ } \\
\text { week }\end{array}$ & $\begin{array}{l}\text { Average } \\
\text { Feed consumption } \\
\text { (g/bird/week) }\end{array}$ & FCR \\
\hline & & & & Starter & Phase & & \\
\hline 1 & 0 & 0 & $70.9 \pm 4.2$ & $547.2^{\mathrm{a}} \pm 1.0$ & $182.7 \pm 3.5$ & $302.4 \pm 9.1$ & $1.7 \pm 0.1$ \\
\hline 2 & 25 & 100 & $70.8 \pm 8.3$ & $501.4^{\mathrm{b}} \pm 2.9$ & $166.6 \pm 9.8$ & $284.2 \pm 2.8$ & $1.7 \pm 0.1$ \\
\hline 3 & 25 & 200 & $70.8 \pm 4.2$ & $508.3^{\mathrm{b}} \pm 2.7$ & $169.4 \pm 9.1$ & $284.9 \pm 23.1$ & $1.7 \pm 0.1$ \\
\hline 4 & 25 & 300 & $70.8 \pm 4.2$ & $488.9^{\mathrm{c}} \pm 1.2$ & $162.4 \pm 4.2$ & $266.7 \pm 28.7$ & $1.6 \pm 0.1$ \\
\hline 5 & 50 & 100 & $70.8 \pm 4.2$ & $476.9^{c} \pm 3.5$ & $158.2 \pm 11.9$ & $280.0 \pm 7.0$ & $1.8 \pm 0.1$ \\
\hline 6 & 50 & 200 & $70.8 \pm 4.2$ & $461.1^{\mathrm{d}} \pm 3.0$ & $154.0 \pm 9.8$ & $263.2 \pm 7.7$ & $1.7 \pm 0.1$ \\
\hline \multirow[t]{2}{*}{7} & 50 & 300 & $70.1 \pm 2.4$ & $490.3^{c} \pm 4.8$ & $163.8 \pm 1.4$ & $280.7 \pm 7.7$ & $1.7 \pm 0.1$ \\
\hline & & & & Finisher & Phase & & \\
\hline 1 & 0 & 0 & $670 \pm 0.5$ & $1790 \pm 0.9$ & $352.1 \pm 47.6$ & $915.6 \pm 9.1$ & $2.6 \pm 0.2$ \\
\hline 2 & 25 & 100 & $670 \pm 0.5$ & $1790 \pm 0.4$ & $353.5 \pm 21.0$ & $906.5 \pm 9.1$ & $2.6 \pm 0.1$ \\
\hline 3 & 25 & 200 & $670 \pm 0.4$ & $1800 \pm 0.4$ & $374.5 \pm 8.4$ & $954.8 \pm 1.8$ & $2.6 \pm 0.1$ \\
\hline 4 & 25 & 300 & $680 \pm 0.2$ & $1770 \pm 0.6$ & $366.1 \pm 6.4$ & $927.5 \pm 2.1$ & $2.5 \pm 0.1$ \\
\hline 5 & 50 & 100 & $670 \pm 0.3$ & $1660 \pm 0.7$ & $329.7 \pm 14.7$ & $927.5 \pm 1.9$ & $2.8 \pm 0.1$ \\
\hline 6 & 50 & 200 & $670 \pm 0.2$ & $1710 \pm 0.6$ & $345.1 \pm 23.1$ & $929.6 \pm 3.8$ & $2.6 \pm 0.2$ \\
\hline 7 & 50 & 300 & $680 \pm 0.4$ & $1750 \pm 0.5$ & $359.8 \pm 18.9$ & $953.4 \pm 1.5$ & $2.7 \pm 0.2$ \\
\hline
\end{tabular}


Table 3: Haematological variables in starter-broiler fed maize offal-based diets with roxazyme-G supplementation.

\begin{tabular}{|c|c|c|c|c|c|c|c|c|}
\hline Diets & $\begin{array}{l}\text { \% Maize } \\
\text { replaced with } \\
\text { maize offal }\end{array}$ & $\begin{array}{l}\text { Enzyme } \\
\text { inclusion } \\
\left(\mathrm{mg} \mathrm{kg}^{-1}\right)\end{array}$ & $\begin{array}{l}\text { Packed Cell } \\
\text { Volume } \\
(\%)\end{array}$ & $\begin{array}{l}\text { Red blood } \\
\text { Cell } x \\
10^{6} \mathrm{~mm}^{3}\end{array}$ & 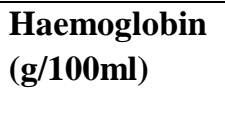 & $\begin{array}{l}\text { MCHC } \\
(\%)\end{array}$ & $\begin{array}{l}\text { MCV } \\
\left(\mu^{3} \mathrm{~m}\right)\end{array}$ & $\begin{array}{l}\text { ESR } \\
(\mathrm{mm} / \mathrm{hr})\end{array}$ \\
\hline 1 & 0 & 0 & $28.0 \pm 2.0$ & $1.9 \pm 0.3$ & $4.3 \pm 1.4$ & $15.4 \pm 4.3$ & $147.4 \pm 1.8$ & $2.5 \pm 0.5$ \\
\hline 2 & 25 & 100 & $25.3 \pm 1.7$ & $1.9 \pm 0.3$ & $4.2 \pm 3.4$ & $16.6 \pm 5.6$ & $133.3 \pm 2.4$ & $3.2 \pm 1.0$ \\
\hline 3 & 25 & 200 & $26.3 \pm 2.4$ & $3.0 \pm 0.8$ & $5.1 \pm 3.4$ & $19.4 \pm 2.8$ & $90.7 \pm 2.1$ & $3.5 \pm 0.9$ \\
\hline 4 & 25 & 300 & $25.3 \pm 3.2$ & $2.2 \pm 0.4$ & $4.0 \pm 0.8$ & $15.8 \pm 4.7$ & $121.0 \pm 3.3$ & $3.3 \pm 0.6$ \\
\hline 5 & 50 & 100 & $28.0 \pm 1.7$ & $2.3 \pm 0.7$ & $5.1 \pm 3.4$ & $18.2 \pm 3.5$ & $128.3 \pm 3.3$ & $3.3 \pm 0.6$ \\
\hline 6 & 50 & 200 & $28.3 \pm 1.2$ & $3.0 \pm 1.3$ & $5.3 \pm 3.6$ & $18.7 \pm 2.1$ & $123.8 \pm 4.7$ & $3.7 \pm 0.6$ \\
\hline 7 & 50 & 300 & $26.3 \pm 4.5$ & $3.0 \pm 0.7$ & $5.1 \pm 0.0$ & $19.4 \pm 2.3$ & $93.2 \pm 2.1$ & $4.3 \pm 1.5$ \\
\hline
\end{tabular}

column are significantly different $(\mathrm{P} \leq 0.05)$. 
Table 4: Haematological variables in broiler - finishers fed maize offal-based diets with roxazyme-G supplementation.

\begin{tabular}{|c|c|c|c|c|c|c|c|c|}
\hline Diets & $\begin{array}{l}\text { Levels of maize } \\
\text { replaced by maize } \\
\text { offal }(\%)\end{array}$ & $\begin{array}{l}\text { Enzyme } \\
\text { Inclusion Level } \\
\left(\mathrm{mg} \mathrm{kg}^{-1}\right)\end{array}$ & $\begin{array}{l}\text { Packed Cell } \\
\text { Volume } \\
(\%)\end{array}$ & $\begin{array}{l}\text { Red Blood Cell } \\
\left(\times 10^{6} \mathrm{~mm}^{3}\right)\end{array}$ & $\begin{array}{l}\text { Haemoglobin } \\
(\mathrm{g} / 100 \mathrm{ml})\end{array}$ & $\begin{array}{l}\text { MCHC } \\
(\%)\end{array}$ & $\begin{array}{l}\text { MCV } \\
\left(\mu \mathrm{m}^{3}\right)\end{array}$ & $\begin{array}{l}\text { ESR } \\
(\mathrm{mm} / \mathrm{hr})\end{array}$ \\
\hline 1 & 0 & 0 & $32.0 \pm 2.6$ & $2.9 \pm 0.1$ & $10.7 \pm 3.5$ & $33.3 \pm 10.6$ & $110.1 \pm 4.2$ & $1.7 \pm 0.6$ \\
\hline 2 & 25 & 100 & $31.7 \pm 1.2$ & $2.9 \pm 0.2$ & $8.6 \pm 3.9$ & $27.6 \pm 13.2$ & $109.2 \pm 5.1$ & $1.5 \pm 0.3$ \\
\hline 3 & 25 & 200 & $28.3 \pm 4.0$ & $2.9 \pm 0.4$ & $10.5 \pm 0.8$ & $37.3 \pm 4.5$ & $97.3 \pm 10.1$ & $3.0 \pm 0.8$ \\
\hline 5 & 50 & 100 & $28.7 \pm 2.1$ & $2.8 \pm 0.1$ & $9.3 \pm 2.2$ & $32.5 \pm 7.1$ & $102.8 \pm 1.8$ & $1.7 \pm 0.6$ \\
\hline 6 & 50 & 200 & $30.0 \pm 2.7$ & $3.0 \pm 0.4$ & $10.9 \pm 2.7$ & $36.0 \pm 6.3$ & $100.6 \pm 6.3$ & $1.5 \pm 0.0$ \\
\hline 7 & 50 & 300 & $26.3 \pm 0.6$ & $2.6 \pm 0.1$ & $6.4 \pm 2.1$ & $24.2 \pm 7.9$ & $102.2 \pm 3.3$ & $2.0 \pm 0.0$ \\
\hline
\end{tabular}


cellular haemoglobin contents irrespective of the levels of maize offal and roxazyme- $G$ inclusion in the diets. The relevance of MCHC measurement lies in its use in the diagnosis of anaemia and also as an index of the capacity of bone marrow to produce RBC (Aletor and Egberongbe, 1992).

From the forgoing, $132.3 \mathrm{~g} \mathrm{~kg}^{-1}$ maize offal $+200 \mathrm{mg} \mathrm{kg}^{-1}$ roxazyme- $G$ and $142.3 \mathrm{~g}$ $\mathrm{kg}^{-1}$ maize offal $+200 \mathrm{mg} \mathrm{kg}^{-1}$ roxazyme-G appeared to be the optimal levels of inclusion for both maize offal and roxayzme- $G$ supplementation for chicks and growing broilers diets, respectively.

\section{REFERENCES}

Agbede JO, Ajaja K, Aletor VA. 2002. Influence of roxazyme $G$ supplementation on the utilization of Sorghum Dust-based diets for broiler-chicks. Proc. of $27^{\text {th }}$ Annual NSAP Conference, Akure, Nigeria, pp 105-108.

Agbede JO, Ajaja K, Aletor VA. 2005. Response of broiler chicks to roxazyme- $G$ supplemented diets in which wheat offal and rice bran replaced maize. Appl. Trop. Agric., 10: 39 - 43.

Aletor VA, Egberongbe O. 1992. Feeding differently processed soybean. Part 2: An assessment of haematological responses in the chickens. Die Nahrung, 36: 364369.

Alp M, Kahraman R, Kocabagu N, Abas I, Aksu H. 1999. Effect of different enzyme supplementation on the performance and ileal $\mathrm{pH}$ of broilers fed wheat- and barleybased diets. Turk. J. Vet. Anim. Sci, 23(3): 617-622.

AOAC. 1990. Official Method of Analysis (15th edn). Association of Officiating Analytical Chemist: Washington D.C.
Aro SO, Agbede JO, Aletor VA, Tewe OO, Ashimi AA. 2010. Performance and economics of production of growing pigs fed microbially enhanced cassava tuber waste diets. Proceedings of the $1^{\text {st }}$ Nigerian international pig summit, Institute of Agricultural Research \& Training, Moor Plantation, Ibadan, Nigeria, 22-25 November, 2010, Adesehinwa AOK, Akinfala EO, Omole AJ, Makanjuola BA (eds), 78-85.

Awoniyi TAM, Adebayo IA, Aletor VA. 2004. A study of some erythrocyte indices and bacteriological analysis of broiler-chickens raised on maggot-meal based diets. Int. J. Poult. Sci., 3(6): 386390.

Iyayi EA. 2004. Changes in the cellulose, sugar and crude protein contents of Agroindustrial by-products fermented with Aspergillus niger, Aspergillus flavus and Penicillium spp. Afr. J. Biotech., 3(3): 186-188.

Lamb GN. 1981. Manual of Veterinary Laboratory Technique. CBA-GEIGY: Kenya; 98-107.

Laseinde EAO, Oluyemi JA. 1997. Sexual dimorphism in the growth pattern of broiler under different dietary and housing conditions. Nig. J. Anim. Prod., 24: 1-6.

Nnenna OP, Emeka NP, Okpoko CL. 2006. Performance of broiler chicks (Gallus domesticus) fed maize offal-based diets supplemented with roxazyme- $G$ enzyme. Int. J. Poult. Sci., 5(7): 607-610.

NRC. 1994. Nutrient Requirements of Poultry. National Academy Press: Washington, DC.

Ojewola GS, Oguike MA, Akomas SC, Likita T, Onyiro OM, Wokocha C. 2003. Comparison of the supplemental effects 
of roxazyme-G enzyme in palm kernel meal and brewers dried grain based diets fed to male Turkey poults. Nig. Agric. J., 34: 116-124.

Piston SM, Seviour RJ, Mc Dougall BM. 1993. Non cellulolytic fungal glucanases: Their physiology and regulation. Enzy. Microbial Tech., 15: 178 - 192.

SPSS. 2006. Statistical Package for Social Scientists. S.P.S.S Base 15.0 User's Guide, Copyright 2006. S.P.S.S. Inc., 233
South Wacker Drive, $11^{\text {th }}$ Floor, Chicago, IL 60606-6412.

Uko JO, Ataja AM, Tanko HB.1999. Response of rabbits to cereal byproducts as energy sources in diets. Arch. Zootec., 48: 285 - 294.

Vranjes MV, Wenk C. 1995. Influence of dietary enzyme complex on the performance of broilers fed on diets with and without antibiotic supplementation. Brit. Poult. Sci.., 36(2): 265-275. 